It expands and contracts in an apparently normal manner. 'We vesicular murmur can be plainly heard in it, and per: cussion gives the same note as obtained from fresh lungs. 'The process wil! be seen to be a modification of the old slycerine-carbolic method, well known and often used to preserve anatornical specimens in an elastic condition. 'The modifications ale important, however; and the results far better than any obtained in the old way. The idea of the method is; first, to fix the tissues by the chromic and acetic acid solution, then to introduce the glycerine-carbolic solution, and, finally, to get rid of this, and practically to make an 'oil-tanned' lung.'

The composition of the three solutions and the mode of using them are then given. It does not appear that, at that time, he had prepared any specimen of both lungs, or that he subsequently exhibited, or published any descrip. tion of, any such. 'That which he prepared (by his new method) to present to me at New York in the spring of 1892 may perhaps luave been the first. These lungs were slightly pathological. They did not remain in efficient working much more than a year: partly, perhaps, owing to insufticient exercising. Meanwhile, in the early summer of 1892, I prepared, according to his latest directions, a perfectly noimal and complete specimen of both lungs with trachea. This was a complete success. It was long used for demonstration at St. George's Hospital; and it still preserves its elasticity after the lapse of nearly twenty-three years. Unhappily, through a preventable accident, it has quite recently developed a bad "puncture" which now disables it, though it is still inflatable, for any complete and lasting inflation. : That long: record, and the fear lest, owing to his untimely death, the value of his latest method might otherwise be lost to science, make me anxious to publish those simple directions which enabled me to secure that success, without the luelp of any actual demonstration of his technique, or of any know. ledge of the published details of his earlier method.

"Improved Method for Preparing Lungs in order to Preserve their Elasticity and Gross Anatomical Appearance.--'The lungs must be removed intact, and the pul. monary blood vessels cut as close to the heart as possible. If it is intended to prepare both lungs the trachea should be cut as high as possible. If only one is prepared, cut the bronchus at its junction with the trachea. Insert and tie as large a cannula as possible in the bronchus or trachea, and in the pulmonary artery."

"1. Take of Miiller's fluid 1,000 and of acetic acid 75 . Fill the lungs through the air passages, and suspend them in solution for twenty-four or forty-eight hours; height of funnel not more than $3 \mathrm{ft}$. 2. Inject through the artei:y a mixture of glycerine 4, carbolic acid 1. 3. Dry as well as possible by suction applied to the air passages, then inject through the artery, under pressure of 5 or $6 \mathrm{ft}$. of water, cotton-seed oil 100, oil of origanum 10. Dry as well as possible, and lieep in a crock:"

\section{Its Plyysiology}

The "Rooserelt elastic lung" is therefore remarkable for its durability as a whole; but much more so for that of its elastic fibre and of the elastic function in it. A striling contrast is displayed between the pathological history of the fibre in life and its artificial history under preservation in death. As shown by emphysema and by obesity, it is more prone than most living tissues to mechanical destruction by overuse or disuse. As shown by arterial degeneration, and by vascular syphilis, it is also exceedingly liable to destruction by microbes and by phagocytosis. This is doubtless correlated with an extremely low coefficient of nutritional activity and requirement; which is fully demonstrated by its endurance, when it is adequately protected against the scavcugers of death.

We know little about it. But we do know that it is the last to die; and that it is also our ultimum movens, when, by a final vital re soil, the all-pervading "elastic skeleton of configuration" restores our normal lineaments after their muscular rigidity. That enigma, the last we have approached, might well hold our solution for another problem, not the least important of those yet to be solved -"the mechanics of our biomorphology." If, as it appears, the elastic fibre has in its mechanical keeping our individual polyorganic architecture, might it not conceivably be itself the builder ; and, if so, the missing link between our physics and our vital energy? Adami's striking conception of "fibrogenesis" as a linear intraplasmatic crystallization along each line of movement and of stress is suggestive of a great mechanical antithesis. Our "rigid" skeleton of support is mineralized through "rest"; our "pulsatile" elastic skeleton of organic architecture and nutivition would be the direct mechanical product from the individual. In vital " work," too, might possibly lie the true explanation for our chief clinical puzzle. The extreme diversity in our "nomal" individual "sphygmopiesis" might be but an expression of the diversity in our "physical" or elastic coefficient, as the inviolable or irreducible individual factor in our - vital "dynamic equation" between the nervo-muscular heart and the neuromyo-elastic artery.

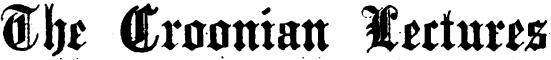

ox

\section{TRTPANOSONES CAUSING DISEASE IN MAN ANI) DONESTIC ANIMALS IN CENTRAL} AFRICA.

Delivered before the Royal College of Physictans of Londow,

By SIR DAVID BRUCE, C.B., F.R.C.P., F.R.S., SERGEON-(FENERAT, A.M.S. ; LATE DIRECTON of THE ROYAI

\section{LECTURE IV}

Is this concluding lecture I intend to sketch briefly the outstanding features of the trypanosomes belonging to Groups $B$ and $C$. As far as we are aware, none of the tiypanosomes attack man. They are, therefore, of less interest to us than the two species already described.

\section{GROUP B.-THE TRYPANOSOMA PECORUM GROUP.}

\section{1. 'Trypanosoma pecorum.}

The first of this small group, which only consists of two species, is Trypanosoma pecorum. It is probably the most important trypanosome disease of domestic animals in Central Africa.

Fig. I shows its general appearance. It is the smallest of all the African pathogenic trypanosomes, varying from 9 to 18 microns in length, with an average of 14 microns.

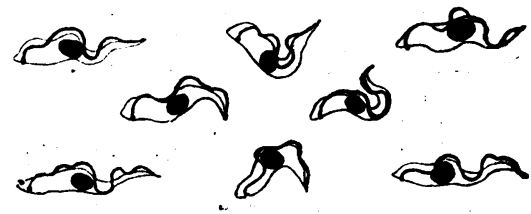

Fig. 1.-Trypanosoma pecorum.

Its breadth averages 1.96. This species is monomorplic, and sliort and stout in form. The contents of the cell are generally homogeneous. The nucleus is oval in shape, and situated about the middle of the body. The micro nucleus is small and round, and situated near to, but not at the posterior extremity, and often appears to project beyond the edge of the trypanosome. The undulating membrane is simple, but fairly well developed, and there is no free flagellum.

There ought to be no difficulty in recognizing this species fiom morphology alone. If one or two liundred are drawn and measured, the average length would separate it from its neighbour Trypanosoma simiae. Another small trypanosome, Trypanosoma uniforme, differs in shape and in liaving a free flagellum.

Animals Susceptible to Trypanosoma pecorum.

Next in regard to the animals attacked by this trypano. some. This is essentially a disease of the herds. Horses, donkeys, oxen, goats, sheep, and pigs all fall victims.

One peculiarity about Trypanosoma pecorum is that it readily loses its virulence for certain animals by passage through certain other animals. For example, if this species-which is usually more or less infective to the monkey, dog, and rat-lives for some time in the blood of 
the goat, it loses its power of infecting the former animals. This has given rise to the erroneous idea that a species, T'rypanosoma nanum, exists. Trypanosoma nanum is in truth nothing but a strain of Trypanosoma pecorum which has lost its virulence for the other animals by its passage through the goat or allied species.

TABLE I.

Average Duration of Life, in Days, of Various Animals infectcd by Trypanosoma pecorum.

\begin{tabular}{|c|c|c|c|c|}
\hline & & & $\begin{array}{l}\text { Averase } \\
\text { Duration } \\
\text { in Dayss. }\end{array}$ & $\begin{array}{c}\text { No. of } \\
\text { Animals } \\
\text { Employed. }\end{array}$ \\
\hline onkey ... & & $\ldots$ & $\ldots 87$ (?) & 1 \\
\hline ttle $\ldots$ & $\ldots$ & $\ldots$ & $\ldots \quad 121$ (?) & $\ldots$ \\
\hline oat $\ldots$ & $\ldots$ & $\ldots$ & $\ldots \quad 55$ & 59 \\
\hline & $\ldots$ & $\ldots$ & 1... & 1 \\
\hline Monkey... & $\ldots$ & $\ldots$ & $\ldots .1 .1$ & 11. \\
\hline$\ldots$ & $\ldots$ & $\ldots$ & $\ldots 43$ & 57 \\
\hline Guinea-pig & $\ldots$ & $\ldots$ & $\ldots \quad 41$ & 5 \\
\hline Rat. & $\ldots$ & $\ldots$ & $\ldots \quad 33$ & 10 \\
\hline
\end{tabular}

Percentage of Recoceries in Various Animals from Trupanosoma pecortum Injection.

Percentages. No of Animals

\begin{tabular}{lccccrrr}
\multicolumn{1}{l}{} & & & \multicolumn{2}{c}{ Emplo } \\
Donkey $\ldots$ & $\ldots$ & $\ldots$ & $\ldots$ & 80 & $\ldots$ & 5 \\
Cattle & $\ldots$ & $\ldots$ & $\ldots$ & $\ldots$ & 35 & $\ldots$ & 17 \\
Goat & $\ldots$ & $\ldots$ & $\ldots$ & $\ldots$ & 12 & $\ldots$ & 70 \\
Pig & $\ldots$ & $\ldots$ & $\ldots$ & $\ldots$ & 0 & $\ldots$ & 1 \\
Monkey $\ldots$ & $\ldots$ & $\ldots$ & $\ldots$ & 0 & $\ldots$ & 11 \\
Dog & $\ldots$ & $\ldots$ & $\ldots$ & $\ldots$ & 1 & $\ldots$ & 63 \\
Guinea-pig & $\ldots$ & $\ldots$ & $\ldots$ & 0 & $\ldots$ & 5 \\
Rat $\ldots$ & $\ldots$ & $\ldots$ & $\ldots$ & 0 & $\ldots$ & 10
\end{tabular}

This trypanosome docs not seem to be very fatal to horses, mules, or donkeys. In Nyasaland there was no opportunity of testing it on horses, but out of five donkeys four recovered. Two-thirds of the cattle, and seven-eighths of the goats, succumbed.

The Carrier of Trypanosoma pecorum.

The chief carrier of 'Trypanosoma pecorum is Glossina morsitans. I am not aware of this trypanosome ever having been found in Nature in Glossina palpalis. In Uganda, where we made many feeding experiments with the wild Glossina palpalis, in not a single instance did a T'rypanosoma pecorum infection take place. In Nyasaland, on the other hand, this parasite was the commonest of the trypanosomes with which Glossina morsitans was infected, as the followirg table will show.

TABLE II.-Proportion of Tsetse Flies (Glossina morsitans) Vaturally Infective rith Trypanosoma pecormm in Nyasaland.

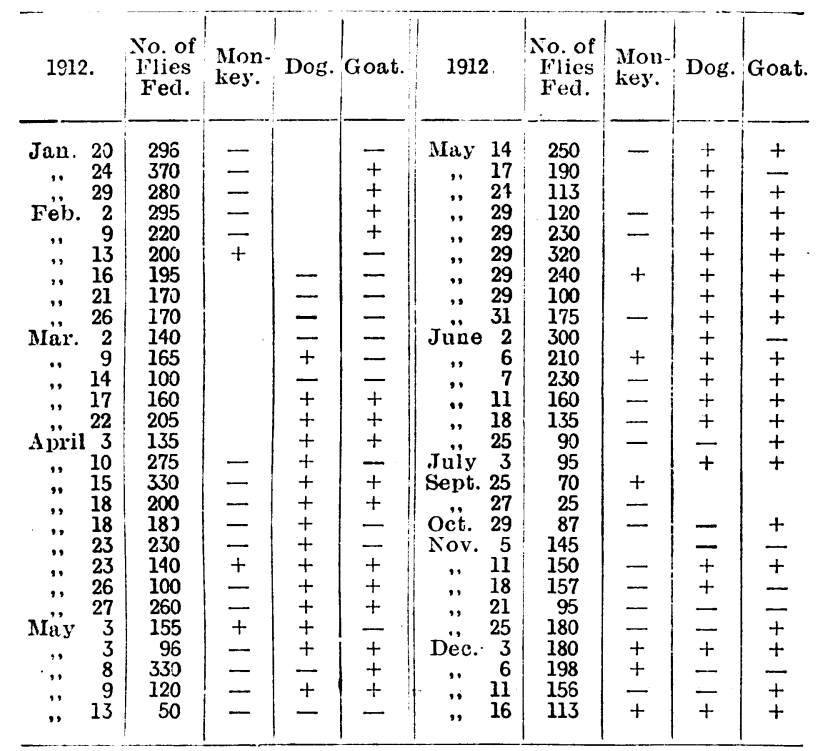

It will be seen from Table II that there were 56 experiments, and 10,081 tsetse flies (Glossina morsitans) were employed. In the 56 experiments Trypanosoma pecorum was found 46 times, more than twice as often as Trypano. soma brucei.

Nine monkeys, $34 \mathrm{dogs}$, and 35 goats were infected.
This gives a proportion of 4.6 per 1,000 flies infective with Trypanosoma pecorum. It is therefore abundantly evident that Glossina morsitans is a carrier of this trypanosome under natural conditions. But when once this disease has infected a herd there is some circumstantial evidence available to show that the infection may be spread by means of the ordinary cattle or buffalo flies, the Tabanidae.

The ordinary horse-fly of England belongs to this genus, and it is a matter of common experience that these flies give a severe bite or stab, as a rule drawing blood.

These Tabanidae are in their habits and distribution quite different from the tsetse flies. At a particular place for the greater part of the year they may be absent or rare, but at certain times they suddenly appear in enormous numbers, only to disappear again in a few weeks. When swarming in this way they are a veritable pest to cattle. The flies feed mostly at the hottest time of the day, and the cattle to protect themselves crowd together, so as to expose as small a surface of their bodies as possible. If there are any infected animals in the herd the conditions could not be more favourable for mechanical transmission. The infected animals are close beside the healthy, and the flies pass from one to another almost instantaneously.

In Uganda we had an opportunity of studying a sudden epidemic of this disease in a herd of milch cattle. In the course of two months 34 of the cows died out of a herd of 300. The evidence was all agairst this epidemic having been caused by tsetse flies.

For four months we had as many as 100 fly boys scouring the district for biting flies, but not a single tsetse fly was captured. We therefore came to the conclusion that one or more infected animals having got accidentally into the herd, the infection was spread by one of these swarms of Tabanidae. As soon as the affected animals were removed from the herd the epidemic ceased.

Another example of the same kind occurred among our experimental cattle at Mpumu in Uganda. The Tabanidae, which had been rare, suddenly appeared in swarms. They were first seen in the valley to the west of the hill in September, 1909, and a month later in the valley to the east. Soon after this the cattle, which had shown no signs of disease during the previous year, were found to be suffering from Trypanosoma pecorum. Those which grazed in the valley to the west were first affected, and afterwards those which grazed to the east of the hill.

Another writer, George E. Owen, has come to the same conclusion. He states that between 1908 and 1913 some 2,500 to 3,000 head of cattle died from trypanosome disease in the Barotse Reserve of Northern Rhodesia, though this district is free from Glossina morsitans. The mortality began each year in February and practically ceased after June. December and March are the months when flies are most numerous.

In $1912 \mathrm{Mr}$. Owen was sent to investigate, and was able to keep a herd of 800 without loss through 1813. The animals were carefully watched for six months during the season when the flies were scarce, and all the infected or suspected cattle removed before the flies again became numerous.

It may therefore, I think, be concluded with a fair degree of certainty that the trypanosome disease caused by Trypanosoma pecorum can be carried from sick to healthy animals by biting flies other than Glossinae. What happens, probably, is this. One or more oxen previously exposed to the bites of tsetses are introduced into the herd living in a tsetse free district, and from these few infected animals the disease is spread by the Tabanidae.

I must apologize for discussing this point at such a length, but it is an important one, and shows how necessary it is that cattle owners living outside tsetse areas should keep strict watch on their herds in order to pre. vent the presence of trypanosome-infected cattle among them. They should include a microscope in their outfit.

\section{The Cycle of Development of Trypanosoma pecorum} ini Glossina morsitans.

This trypanosome belongs to Group B, in which development takes place first in the gut and then passes forward into the labial cavity of the proboscis, and finally reaches the salivary duct or hypopharynx, where the trypanosomes revert to the original blood form and become infective. There is no infection of the salivary glands. 


\begin{tabular}{|c|c|c|c|c|c|c|}
\hline Date. & Expt. & $\begin{array}{l}\text { No. of } \\
\text { biies } \\
\text { Used. }\end{array}$ & $\begin{array}{c}\text { Experi- } \\
\text { ment } \\
\text { Positive } \\
\text { or } \\
\text { Negative. }\end{array}$ & $\begin{array}{l}\text { No. of } \\
\text { Infected } \\
\text { Flies } \\
\text { Found. }\end{array}$ & $\begin{array}{c}\text { No. of } \\
\text { Days be- } \\
\text { fore Flies } \\
\text { became } \\
\text { Infective. }\end{array}$ & $\frac{\text { Mean }}{\text { Temperature. }}$ \\
\hline $\begin{array}{c}1912 . \\
\text { May } 16 \ldots\end{array}$ & 516 & 22 & + & 4 & 53 & $69^{\circ} \mathrm{F} .\left(20.5^{\circ} \mathrm{C}.\right)$. \\
\hline July $2 \ldots$ & 524 & 20 & + & 2 & 37 & 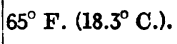 \\
\hline $\begin{array}{l}1913 . \\
\operatorname{Jan} .3\end{array}$ & 1732 & 60 & - & 0 & 一 & $84^{\circ}$ F. $\left(28.8^{\circ}\right.$ C.) \\
\hline Jan. 7 & i 737 & 40 & + & 3 & 19 & $84^{\circ}$ F. $\left(28.8^{\circ}\right.$ C. $)$. \\
\hline Feb. 10. & 1853 & 25 & + & 5 & 24 & $84^{\circ}$ F. $\left(28.8^{\circ}\right.$ C. $)$. \\
\hline Teb. $24 .$. & 1950 & 33 & + & 6 & 21 & $84^{\circ} \mathrm{F} .\left(28.8^{\circ} \mathrm{C}.\right)$. \\
\hline pril $29 \ldots$ & 2115 & 40 & - & 4 & - & $84^{\wedge}$ F. $\left(288^{\circ}\right.$ C.). \\
\hline
\end{tabular}

Seven experiments were carried out with laboratory. bred flies. Five were positive and two. negative.

Two hundred and forty flies were used, and twenty-four in. fected flies found (10 per cent.). 'The first two experiments were carried out at the ordinary temperature of the laboratory; in the other's the flies were kept in the incubator.

It would appear from these five positive experiments that a period of from nineteen to fifty." three days may elapse before the cycle of develop. ment of Trypano. soma pecorum in Glossina morsi. tans is complete and the fly becomes infective.
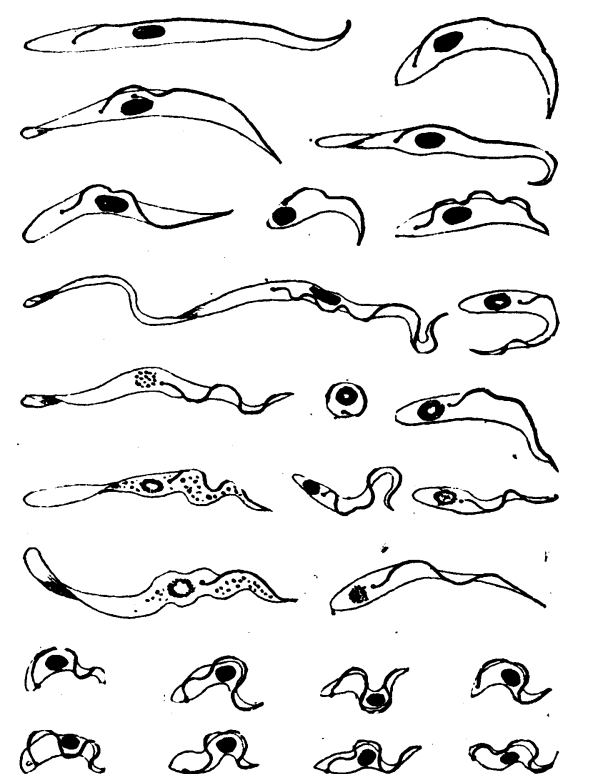

Fig. 2.-Trypanosoma pecorum from proboscis,

Result of the Dissection of the Infected Flies.

Table IV gives the result of the dissection of the twenty infected flies found in the positive experiments. The second column gives the number of days between the first feed of the fly and its death and dissection.

TABLE IV.-Result of the Disscction of the Infected Flies. (Laboratory-bred Flics. Positive Experiments.)

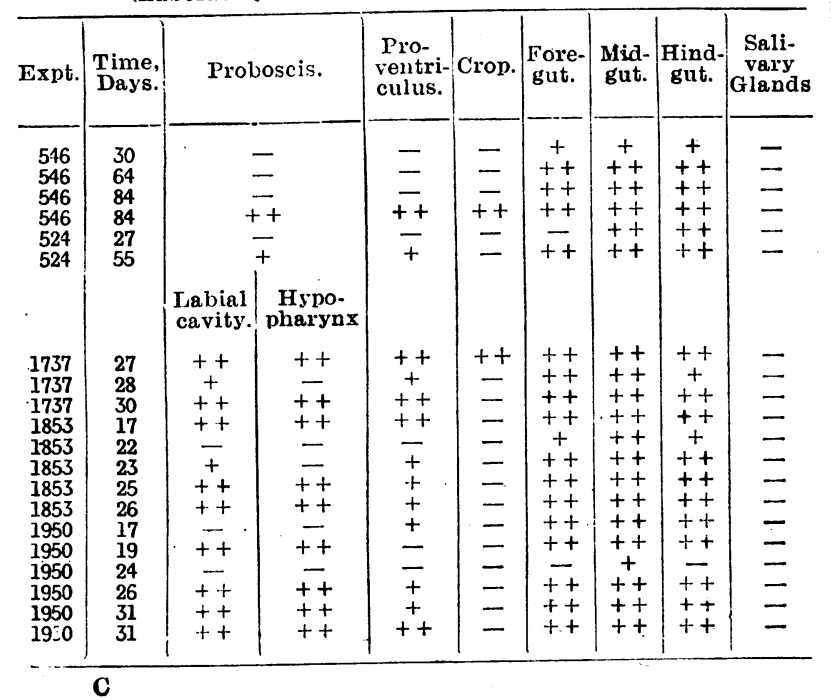

Table V.-Showing the Result of the Dissection of the Infected Flies in the Negative Experiments.

(Laboratory-bred Flies.)

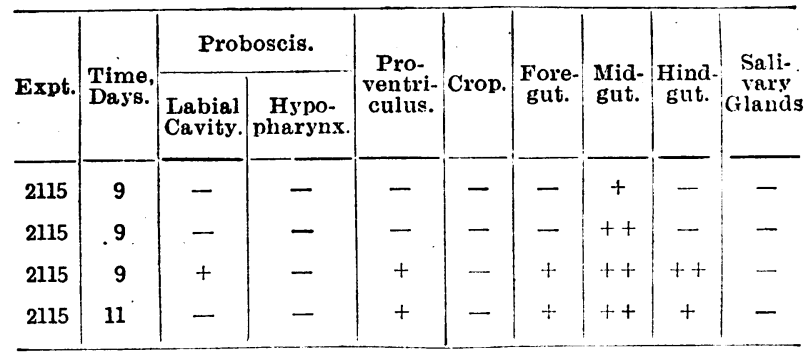

In Experiments 546 and 524 there was no separate examination of the hypopharynx; it is included in the general term "proboscis." It was only when the im. portance of the hypopharynx became evident that an

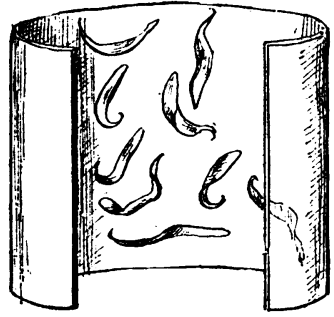

Labrum: early infection.

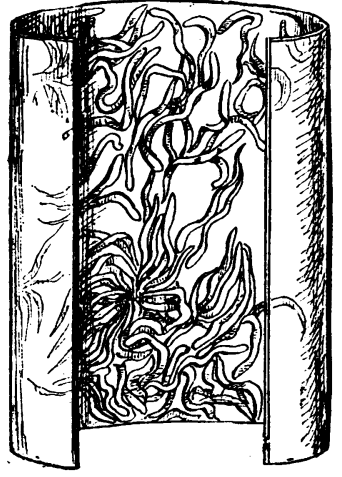

Labrum examination of the separate parts of the proboscis was made. In not a single fly was any invasion of the salivary glands noted, but it will be seen that in every positive experiment try. panosomes are found in the hypopharynx.

So much for the positive experiments; let us see what is the result of the dissection of the infected flies in the negative experiments. In none of the in. fected flies had development reached the hypo. pharynx, and consequently none of the flies had become in. fective.

From the consideration of these tables it will be seen that in Trypanosoma pecorum the development talies place at first in the intestine, then passes forward into the labial cavity, and finally invades the lypopharynx, and there is completed.

\section{The Type of Trypanosomes found in the Infected} Flies.

Fig. 2 represents the developmental forms of Trypanosoma pecorum found in the labial cavity of Glossina morsitans.

In regard to the forms found in the intestine, it may bc said that these are indistinguishable from the develop. mental forms of other pathogenic trypanosomes.

The first seven figures represent early forms in the labial cavity. 'These were seen adhering singly by theil' flagella to the labrum.

The next group are the ordinary forms found clinging by their flagella ends to the labrum. It will be seen that they have assumed the crithidial stage-a stage which seems to be a sine qua non in the final stages of the cyclc of development of all the pathogenic trypanosomes, and the interpretation of which is still obscure.

The small blood forms are from the hypopharyux of dead infective flies, and also from living infective flies induced to salivate on a cover-glass. They represent tho final stage in the cycle of development, and are the only infective forms.

In Fig. 3 are seen drawings, at a magnification of 250 diameters, of the labrum and hypopharynx of a $\mathrm{fly}$ infected with this trypanosome. While the labial carity 
is seen to contain clusters of large ribbon-like trypanosomes, the hypopharynx is swarming with the small infective forms. From these drawings the ease and facility with which a tsetse fly can infect an animal will be readily understood.

Another way of showing how easy it is for a fly to infect an animal is to induce an infected fly to salivate on a cover-glass. If a hungry fly is placed on a large coverglase, which covers a man's finger, the fly will attempt to bite through the glass, and in so doing will smear it with its saliva. If this is then stained and examined under a microscope, thousands of trypanosomes will be seen.

The Reservoir of Trypanosoma pecorum.

Table VI represents the number of times Trypanosoma pecorum was found among the 180 wild animals examined in Nyasaland and the species of game which harboured it.

TABLE VI.-Shouing the Species of Animals Dealt with, the Total
Number Examined, the Number foumd Infected, and the Species of Trypanosome by which they were Infected.

\begin{tabular}{|c|c|c|c|c|c|c|c|}
\hline Animai. & 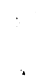 & $\begin{array}{c}\text { No. } \\
\text { Examineā. }\end{array}$ & $\begin{array}{c}\text { No. } \\
\text { Found } \\
\text { Infected. }\end{array}$ & $\begin{array}{l}\text { Tryp } \\
\text { brucei. }\end{array}$ & $\begin{array}{c}\text { Tryp. } \\
\text { pecorum. }\end{array}$ & $\mid \begin{array}{c}\text { Tryp. } \\
\text { simiae. }\end{array}$ & $\begin{array}{c}\text { Trypp. } \\
\text { caprae. }\end{array}$ \\
\hline Eland ... & $\ldots$ & 10 & 6 & 0 & 6 & 0 & 1 \\
\hline Sable ... & $\ldots$ & 5 & 0 & 0 & 0 & 0 & 0 \\
\hline Waterbuck & $\ldots$ & 13 & 9 & 3 & 1 & 0 & 8 \\
\hline Koodoo & $\ldots$ & 3 & 2 & 0 & 2 & 0 & 0 \\
\hline Bushbuck & $\ldots$ & 10 & 7 & 0 & 7 & 0 & 1 \\
\hline Hartebeeste & & 35 & 6 & 5 & 1 & 0 & 0 \\
\hline Reedbuck & $\ldots$ & 19 & 12 & 3 & 1 & 0 & 9 \\
\hline Orobi ... & $\ldots$ & 26 & 4 & 1 & 1 & 0 & 1 \\
\hline Duiker & $\ldots$ & 7 & 2 & 1 & 0 & 0 & o \\
\hline Buffalo & $\ldots$ & 9 & 2 & 0 & 2 & 0 & 0 \\
\hline Lion $\ldots$ & $\cdots$ & 1 & 0 & 0 & 0 & 0 & 0 \\
\hline Hyaena & $\therefore$ & 3 & 2 & 0 & 2 & 0 & 0 \\
\hline Warthog & $\ldots$ & 33 & 7 & 1 & 3 & 3 & 0 \\
\hline Elephant & $\ldots$ & 2 & 0 & 0 & 0 & 0 & 0 \\
\hline Wild cat & $\ldots$ & 3 & 0 & 0 & 0 & 0 & 0 \\
\hline Porcupine & $\therefore$ & 1 & 0 & 0 & 0 & 0 & 0 \\
\hline Total & $\ldots$ & 180 & 59 & 14 & 26 & 3 & 20 \\
\hline
\end{tabular}

It will be seen that 26 animals among the 180 harboured this parasite (14.4 per cent.), and the eland, the koodoo, the bushbuck, and the buffalo were the greatest sinners; 60 per cent. of the eland, 66 per cent. of the koodoo, 70 per cent. of the bushbuck, and 22 per cent. of the buffalo having Trypanosoma pecorum in their blood.

It is rather curious that Trypanosoma pecorum has picked out the animals in whose blood Trypanosoma brucei was absent.

\section{Trypanosoma simiae.}

This species of trypanosome is remarkable for the virukence it displays towards the monkey and the domestic pis, killing these animals in an incredibly short period of time, whereas it is harmless to oxen, antelope, dogs, and the smaller experimental animals. Curiously enough it affects goats and sheep, although oxen and antelope escape.

Trypanosoma simiae is similar to Trypanosoma pecorum in the rapidity with which its virulence becomes modified. If a cage containing wild tsetse flies (Glossina morsitans) infected with this parasite is placed on a monkey or a goat, both animals take the disease and the monkey in such an acute form that the average duration of disease is only a few days.

But if the attempt is made to pass this species of trypauosome from an infected goat to a healthy monkey, by the inoculation of the goat's blood, the experiment usually fails, showing that a short sojourn in the blood of the goat has almost nullified the virulence of the parasite for the monkey.

Euother interesting point in resard to this species is, that as far as is known, the warthog is the only animal among the wild game which harbours it. It is probablo that it will also be found in the blocel of the bush-pig, but that has not been done yet.

\section{Morphology.}

If Fig. 4 be compared with Fig. 1 , it will be seen that Trypanosoma simiae is longer than Trypanosoma pecorum. It is monomorphic, varying from 14 to 24 microns in length-average 18. The trypanosomes are fairly uniform in shape. The body is elongated, undulating, and frequently extends in a straight line. The contents of the cell are clear and free from granules. The nucleus is oval,

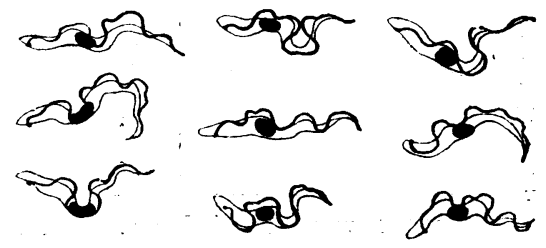

Fig. 4.-Trypanosoma simiae.

and situated about the middle of the body. The micronucleus is small and round, situated almost invariably about $1 \frac{1}{2}$ microns from the posterior extremity. The undulating membrane is well developed and thrown into bold undulations.

It is difficult to say whether this species lias a free flagellum or not. By careful staining and good illumination it would seem in most cases as if the undulating membrane extended to the tip of the flagellum. In some preparations, howerer, the last two or three microns of the flagella appear to be free.

Susceptibility of Animals.

Table VII shows the average duration of life in various animals infected by Trypanosoma simiac, also the percentages of recoveries from the disease.

TABLE VII.

Average Duration of Iife in Various Animals iniceted by T'simiae, Nyasaland. Mixed Infections are not included. (The letter $R$ stands for refractory.)

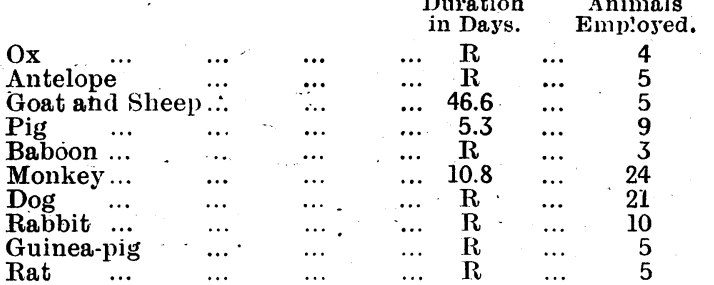

Percentages of Recoreries in Various Lnimals from $T$. simiae Infection. Mired infections are included.

Percentages. No. of Animals

Ox ...
Antelope
Goat and sheep ..
Pig $\ldots$
Baboon ...
Monkey ...
Dog $\ldots$
Rabbit ...
Guinea-pig

Percentages. Employed.

t will be seen that the ox, antelope, baboon, dog, rabbit, guinea-pig, and rat are refractory.

In the whole range of the trypanosome diseases of animals there is surcly nothing so striking as the rapidly fatal action of Trypanosoma simiae on the domestic pig. In nine experiments the average duration was only 5.3 days. This, not from the time of the appearance of the trypano. some in the blood, but from the date of the infection. Further, this rapid action is not the result of an exaltation of virulence by numerous passages through the pig, but natural to the trypanosome.

The Carrier of Trypanosoma simiae.

The carrier of Trypanosoma simiae in Nyasaland is Glossina morsitans. 'Table VIII gives the proportion of flies naturally infectcd w.th this parasite. 


\begin{tabular}{|c|c|c|c|c|c|c|c|c|c|}
\hline \multicolumn{10}{|c|}{$\begin{array}{l}\text { TABLE VIII.-Proportion of Tsetse Flies (Glossina morsitans) } \\
\text { Naturally Infective with Trypanosoma simiae in Nyasaland. }\end{array}$} \\
\hline 1912. & $\begin{array}{l}\text { No. of } \\
\text { Flies } \\
\text { Fed. }\end{array}$ & $\begin{array}{l}\text { Mon- } \\
\text { key. }\end{array}$ & Dog. & Goat. & 1912. & $\begin{array}{l}\text { No. of } \\
\text { Flies } \\
\text { Fed. }\end{array}$ & $\begin{array}{l}\text { Mon- } \\
\text { key. }\end{array}$ & Dog. & Goat. \\
\hline Jan. 20 & 296 & + & & - & May 14 & 250 & + & - & + \\
\hline$\because \quad 24$ & 370. & + & & + & $\because \quad 17$ & 190 & & - & \pm \\
\hline Fëb. ${ }^{29}$ & $\begin{array}{l}280 \\
295\end{array}$ & $\stackrel{+}{+}$ & & $\begin{array}{l}+ \\
+\end{array}$ & ت $\quad 24$ & 113 & - & $=$ & \pm \\
\hline$\| 9$ & 220 & + & & + & $\because \quad 29$ & 230 & - & - & - \\
\hline 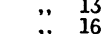 & 200 & & & - & $\begin{aligned} 29 \\
029\end{aligned}$ & 320 & - & $\overline{-}$ & $\bar{z}$ \\
\hline$\because 21$ & 170 & & - & - & $\because \quad 29$ & 100 & 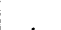 & - & + \\
\hline M̈̈r. $\quad 2$ & 170 & & 二 & \pm & Jüne 21 & 175 & + & $\overline{-}$ & + \\
\hline$" 9$ & 165 & & - & - & . 6 & 210 & - & $=$ & - \\
\hline " 14 & 100 & & - & & " 7 & 23 & $\bar{t}$ & - & $\bar{z}$ \\
\hline$\because \quad 22$ & 205 & & $=$ & + & $\ddot{~}$ & $\begin{array}{l}100 \\
135\end{array}$ & \pm & - & - \\
\hline A pril 3 & 135 & & $=$ & 二 & 25 & 90 & - & - & $=$ \\
\hline$\because \because 15$ & $\begin{array}{l}275 \\
330\end{array}$ & + & $=$ & + & Sept. 25 & 70 & - & & \\
\hline$\because \quad 18$ & 200 & + & - & 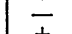 & $\ddot{20}$ & 25 & - & 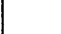 & \\
\hline & 180 & $\stackrel{+}{+}$ & $=$ & + & Oct. 29 & 187 & - & $\bar{z}$ & $=$ \\
\hline$\ddot{\ddot{y}} 23$ & 230 & \pm & - & & $\begin{array}{ll}\text { Nov. } & 5 \\
\text {." }\end{array}$ & $\begin{array}{l}145 \\
150\end{array}$ & + & - & $\bar{z}$ \\
\hline & 100 & 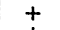 & - & & $\because 18$ & 15 & + & - & + \\
\hline Mด̈ 27 & ${ }_{155}^{260}$ & + & - & 二 & $\begin{array}{l}\| 21 \\
25\end{array}$ & 95 & $\bar{\mp}$ & $=$ & - \\
\hline & 96 & r & - & 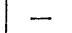 & Dëc. 3 & 180 & + & - & - \\
\hline & 330 & t & - & - & $"$ & & + & - & - \\
\hline$\because \ddot{13}$ & $\begin{array}{r}120 \\
50\end{array}$ & \pm & $\overline{-}$ & $\bar{t}$ & $\ddot{~} \ddot{11}$ & $\begin{array}{l}156 \\
113\end{array}$ & $\begin{array}{l}+ \\
+\end{array}$ & 二 & $=$ \\
\hline
\end{tabular}

As will be seen from this table, there were 56 experiments, and 10,081 tsetse flies were employed. In the 56 experiments Trypanosoma simiae was found 34 times (60.7 per cent.). Twenty-six monkeys and seventeen goats were infected. This gives a proportion of 3.4 per 1,000 flies infective with Trypanosoma simiae. It must be noted that warthogs were numerous in the sleeping sickness area, Nyasaland, which accounts for the fairly high proportion of infected flies.

The Cycle of Development of Trypanosoma simiae in Glossina morsitans.

This species belongs to Group B, and the cycle of development is similar to that which has already been described as occurring in Trypanosoma pecorim.

The Reservoir of Trypanosoma simiae.

In Table VI is shown the number of times Trypano. soma simiae was found among the 180 wild animals examined in Nyasaland, and the species of game which harboured it.

It will be seen that only 3 animals among the 180 harboured this parasite (1.7 per cent.). This was, of course, due to the fact that it is only the warthog among the wild game which acts as a reservoir; 30 wartlogs were examined and 3 found infected ( 9 per cent.).

GROUP C.--THE TRYPANOSOMA VIVAX GROUP.

The three species forming this group have a strong family resemblance, and but for size might almost be included in one species.

\section{Trypanosoma vivax.}

This is the cause of one of the most important diseases of cattle in Uganda. We did not meet with it in Nyasaland, where its place seems to be taken by Trypanosoma caprae. It is, however, widely distributed in Central Africa. It has bren reported from Senegal and the Sudan

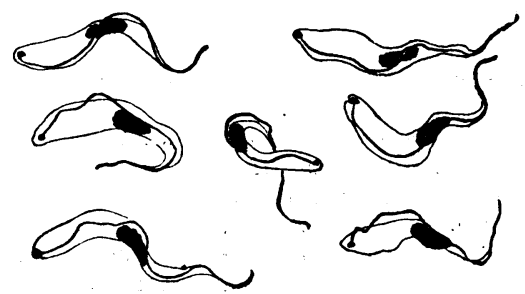

Fig. 5.-Trypanosoma vivax, Ziemann.

in the north to Rhodesia in the south. It is easily recog. nized on accoint of its extreme activity during life, its characteristic morplology in stained specimens, and the fact that it only affects horses, cattle, goats, and sheep, while monkeys, dogs, rabbits, guinea-pigs, rats, and mice are refractory.

In Uganda the tsetse flies on the lake shore were found to be infected with it, and it was also found in the blood of a bushbuck shot at the same place at which the flies were collected.

\section{Trypanosoma uniforme.}

This trypanosome resembles Trypanosoma vivax very closely except that it is smaller. Up to the present it has

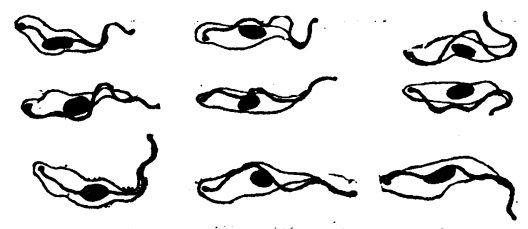

Fig. 6.-Trypanosoma uniforme.

only been found in Uganda. Its carrier there is Glossina palpalis, and its reservoir the wild game on the lake shore.

\section{Trypanosoma caprae.}

This species has only been reported up to the present from Lake Tanganyika and Nyasaland. It, like the other two species belonging to this group, only affects cattle, sheep, and goats. Monkeys, dogs, and the smaller experimental animals are immune.

$$
\text { Morphology. }
$$

Fig. 7 shows its general appearance. During life this trypanosome, like the other members of the group, is characterized by its extreme mobility.
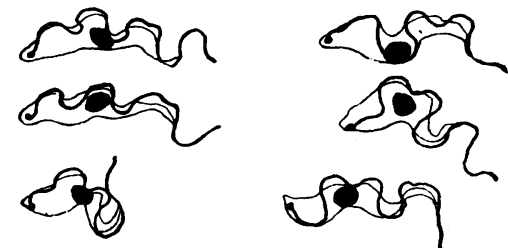

Fig. 7.-Trypanosoma caprae, Kleine.

It is a monomorphic species, varying from 18 to 32 microns in length, the greatest number of individuals being 25 microns long. Measured across the broadest part, Trypanosoma caprae averages 3 microns in breadth (maximum 4.25, minimum 1.75). It differs from Try. panosoma vivax in that it is heavier built and altogether has a larger and clumsier appearance. The posterior half is swollen, and its end is bluntly angular or rounded. The anterior extremity is narrower and pointed. The contents of the cell are clear, with a delicate alveolar structure and free from vacuoles and granules. The nucleus is oval, compact, and lying about the middle of the body. The micronucleus is large and round, situated as a rule close to the posterior extremity; the undulating membrane is more developed than in Trypanosoma viva:x and thrown into bolder folds and undulations. There is a well-marked free flagellum which averages 6.5 microns in length (maximum 9.4, minimum 4).

Susceptibility of Animals to Trypanosoma caprae.

Table IX gives the average duration of the disease, and the percentages of recoveries in various experimental animals.

Average Duration of Life in Various Animals infected by T. caprac, Nyasalund. (The letter $\mathrm{R}$ stands for refractory.)

\begin{tabular}{lccccccc} 
& & & \multicolumn{4}{c}{$\begin{array}{c}\text { Average } \\
\text { Duration } \\
\text { in Days. }\end{array}$} & \multicolumn{2}{c}{$\begin{array}{c}\text { No. of } \\
\text { Animals } \\
\text { Employed. }\end{array}$} \\
Ox & $\ldots$ & $\ldots$ & $\ldots$ & $\ldots$ & - & $\ldots$ & - \\
Goat & $\ldots$ & $\ldots$ & $\ldots$ & $\ldots$ & 56.5 & $\ldots$ & 19 \\
Sheep & $\ldots$ & $\ldots$ & $\ldots$ & $\ldots$ & 115.3 & $\ldots$ & 3 \\
Monkey $\ldots$ & $\ldots$ & $\ldots$ & $\ldots$ & $\mathbf{R}$ & $\ldots$ & 12 \\
Dog & $\ldots$ & $\ldots$ & $\ldots$ & $\ldots$ & $\mathbf{R}$ & $\ldots$ & 12 \\
Guinea-pig & $\ldots$ & $\ldots$ & $\ldots$ & $\mathbf{R}$ & $\ldots$ & 2 \\
Rat & $\ldots$ & $\ldots$ & $\ldots$ & $\ldots$ & $\mathbf{R}$ & $\ldots$ & 2
\end{tabular}

Percentage of Recoveries in Various Animals from $T$. caprae infection.

\begin{tabular}{lccccccc} 
& & & \multicolumn{4}{c}{ Percentages. } & \multicolumn{2}{c}{$\begin{array}{c}\text { No. of Animals } \\
\text { Employed. }\end{array}$} \\
Ox & $\ldots$ & $\ldots$ & $\ldots$ & $\ldots$ & 100 & $\ldots$ & 2 \\
Soat & $\ldots$ & $\ldots$ & $\ldots$ & $\ldots$ & 32.2 & $\ldots$ & 28 \\
Mheep & $\ldots$ & $\ldots$ & $\ldots$ & $\ldots$ & 25.0 & $\ldots$ & 4 \\
Monkey $\ldots$ & $\ldots$ & $\ldots$ & $\ldots$ & $\mathbf{R}$ & $\ldots$ & 12 \\
Dog & $\ldots$ & $\ldots$ & $\ldots$ & $\ldots$ & $\mathbf{R}$ & $\ldots$ & 12 \\
Guinea-pig & $\ldots$ & $\ldots$ & $\ldots$ & $\mathbf{R}$ & $\ldots$ & 2 \\
Rat $\ldots$ & $\ldots$ & $\ldots$ & $\ldots$ & $\mathbf{R}$ & $\ldots$ & 2
\end{tabular}


The Carrier of Trypanosoma caprae.

the carrier of Trypanosoma caprae in Nyasaland is Gilossina morsitans.

Table X shows the proportion of tsetse flies naturally infected with this parasite in Nyasaland. In 56 experiments, in which 10,081 tsetse flies were used, Trypanosoma caprae was found thirty-five times (62.5 per cent.) Since

Table X.-Proportion of Tsetse rlies (Glossina morsitans) Naturally Infective rith Trypanosoma caprae in Nyasalami.

\begin{tabular}{|c|c|c|c|c|c|c|c|c|c|c|}
\hline 1912. & $\begin{array}{l}\text { No of } \\
\text { Flies } \\
\text { Fed. }\end{array}$ & $\begin{array}{l}\text { Mon- }- \\
\text { key. }\end{array}$ & Dog. & Goat. & 1912. & & $\begin{array}{l}\text { No of } \\
\text { Flies } \\
\text { Fed. }\end{array}$ & $\begin{array}{l}\text { Mon- } \\
\text { key. }\end{array}$ & Dog. & toat. \\
\hline Jan. 20 & 296 & - & & $\cdots$ & May & & 250 & 一 & - & + \\
\hline $\begin{array}{ll}, \quad 24 \\
\ddot{2}\end{array}$ & 370 & $\overline{-}$ & & \pm & $"$ & 17 & 190 & & - & + \\
\hline lëb. 29 & 295 & - & $\cdots$ & $\bar{t}$ &, $\bar{y}$ & $\begin{array}{l}24 \\
29\end{array}$ & $\begin{array}{l}113 \\
120\end{array}$ & - & 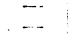 & I \\
\hline$\because \quad 9$ & 220 & $\ldots$ & & + & ," & 29 & 230 & - & - & - \\
\hline " 13 & 200 & - & & + & ," & 29 & 320 & & - & + \\
\hline & 195 & & $-\cdot$ & - & 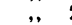 & 29 & 240 & - & - & $\leftarrow$ \\
\hline & 170 & & - & - & & 29 & 100 & & - & + \\
\hline & 170 & & - & 一 & $"$ & 31 & 175 & - & - & - \\
\hline Mar. 2 & 140 & & - & + & June & 2 & 300 & & -. & + \\
\hline & 165 & & $\bar{z}$ & $\begin{array}{l}+ \\
+\end{array}$ & ", & $\begin{array}{ll}6 & \\
7\end{array}$ & 210 & $\bar{z}$ & - & + \\
\hline " 14 & 100 & & $=$ & - & & & $\begin{array}{l}230 \\
160\end{array}$ & $=$ & - & + \\
\hline 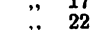 & 205 & & $=$ & $\bar{t}$ & & 18 & $\begin{array}{l}100 \\
135\end{array}$ & - & -. & \pm \\
\hline Apr. 3 & 135 & & - & - & $\ddot{\ddot{2}}$ & 25 & 90 & $\ldots$ & $\ldots$ & + \\
\hline " 10 & 275 & - & $=$ & + & July & 3 & 95 & & - & - \\
\hline " 15 & & $=$ & $=$ & $t_{+}^{+}$ & Sept. & & $\begin{array}{l}70 \\
25\end{array}$ & $=$ & & \\
\hline & 180 & - & - & - & öt & 29 & 87 & E & - & + \\
\hline 23 & 230 & - & - & + & Nov. & 5 & 145 & - & $=$ & + \\
\hline 23 & 140 & - & - & + & , & 11 & 150 & - & $\ldots$ & + \\
\hline " $\quad 26$ & 100 & - & - & - & ", & 18 & 157 & - & - & + \\
\hline $\begin{array}{ll}.8 & 27\end{array}$ & 260 & - & - & t & & 21 & 95 & $\ldots$ & - & $\cdots$ \\
\hline May 3 & 155 & - & & 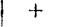 & & 25 & 180 & $\cdots$ & 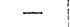 & - \\
\hline 3 & 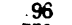 & - & - & - & Dec. & 3 & 18 & - & - & + \\
\hline & 330 & - & - & + & & & 198 & - & - & + \\
\hline & 120 & - & - & + & ", & 11 & 156 & - & - & - \\
\hline " & 50 & - & - & + & ", & & 113 & - & - & + \\
\hline
\end{tabular}

this species is not pathogenic to the monkey or dog, of course it was found only in the experimental goats. This vives a proportion of 3.5 per 1,000 flies infected with Trypanosoma caprae.

The Cycle of Development of Trypanosoma caprue in Glossina morsitans.

'rypanosoma caprae belongs to the Vivax group, in winch the development of the trypanosome is restricted to the proboscis.

TABLF XI.-Development of T. caprac in G. morsitans.

\begin{tabular}{|c|c|c|c|c|c|c|}
\hline Ditie. & Expt. & $\begin{array}{l}\text { No.of } \\
\text { Flies } \\
\text { Used. }\end{array}$ & $\begin{array}{c}\text { Experi- } \\
\text { ment } \\
\text { Positive } \\
\text { or } \\
\text { Negative. }\end{array}$ & $\begin{array}{c}\text { No. of } \\
\text { Infected } \\
\text { Flies } \\
\text { Found. }\end{array}$ & $\begin{array}{c}\text { No. of } \\
\text { Days be- } \\
\text { fore Flies } \\
\text { became } \\
\text { Infective. }\end{array}$ & $\begin{array}{c}\text { Mean } \\
\text { Temperature. }\end{array}$ \\
\hline $\begin{array}{c}1912 . \\
\text { Alril } 16 \ldots\end{array}$ & 444 & 12 & + & 1 & 16 & $71 \mathrm{~F} .(22.1 \mathrm{C})$. \\
\hline June $3 .$. & 617 & 33 & - & 0 & - & $65 \mathrm{~F} .(18.3 \mathrm{C})$. \\
\hline June $3 \ldots$ & 1215 & 22 & + & 1 & $2]$ & $65 \mathrm{~F} .(18.3 \mathrm{C})$. \\
\hline $\begin{array}{c}1913 . \\
\text { Jan' } 18 \ldots\end{array}$ & 1777 & 35 & + & 11 & 19 & 84 F. $(288$ C. $)$ \\
\hline Jan. $22 \ldots$ & 1784 & 35 & + & 20 & 19 & $84 \mathrm{~F} .(28.8 \mathrm{C})$. \\
\hline April l & 2046 & 33 & + & 13 & 20 & $84 \mathrm{~F} .(28.8$ C. $)$ \\
\hline
\end{tabular}

Six experiments were made with laboratory-bred flics; 5 were positive and 1 negative.

One hundred and seventy laboratory bred flies were used and 46 infected flies were found (27.1 per cent). The first thrce experiments were carried out at the ordinary temperature of the laboratory; in the last three the cages containing the flies were kept in an incubator. It is difficult to understand the difference in the number of infected flies found. In Experiments 444 and 1215 only 8 and 5 per ccnt. respectively of the flies became infected, whereas in tho last three experiments an average of more than 40 per cent. was found. The flies in the second group were kept, it is true, at a temperature similar to that which they would fisc in summer in their native haunts in the low country, while the first three experiments were done in winter, and at the ordinary temperature of the laboratory. This would no doubt explain the difference to some extent. Again, goats and sheep infected with Trypanosoma caprae are unsatisfactory animals to ficed flies on. One day the trypanosomes are present in small numbers in the blood, the next day it may be impossible to find any; very seldom are they in large numbers. It is possible, then, that flies may feed on an infected goat or sheep without taking in a single trypanosome.

it would appear from the five positive experiments that an arerage period of nineteen days elapses before the cyclo of development of this parasite is complete in Glossina morsitans, and the fly becomes infective.

Now 46 infected flies were found among 170 user, and the next table gives the result of the dissection of these flies.

TABLE XII--Result of the Dissection of the Infected Tites.

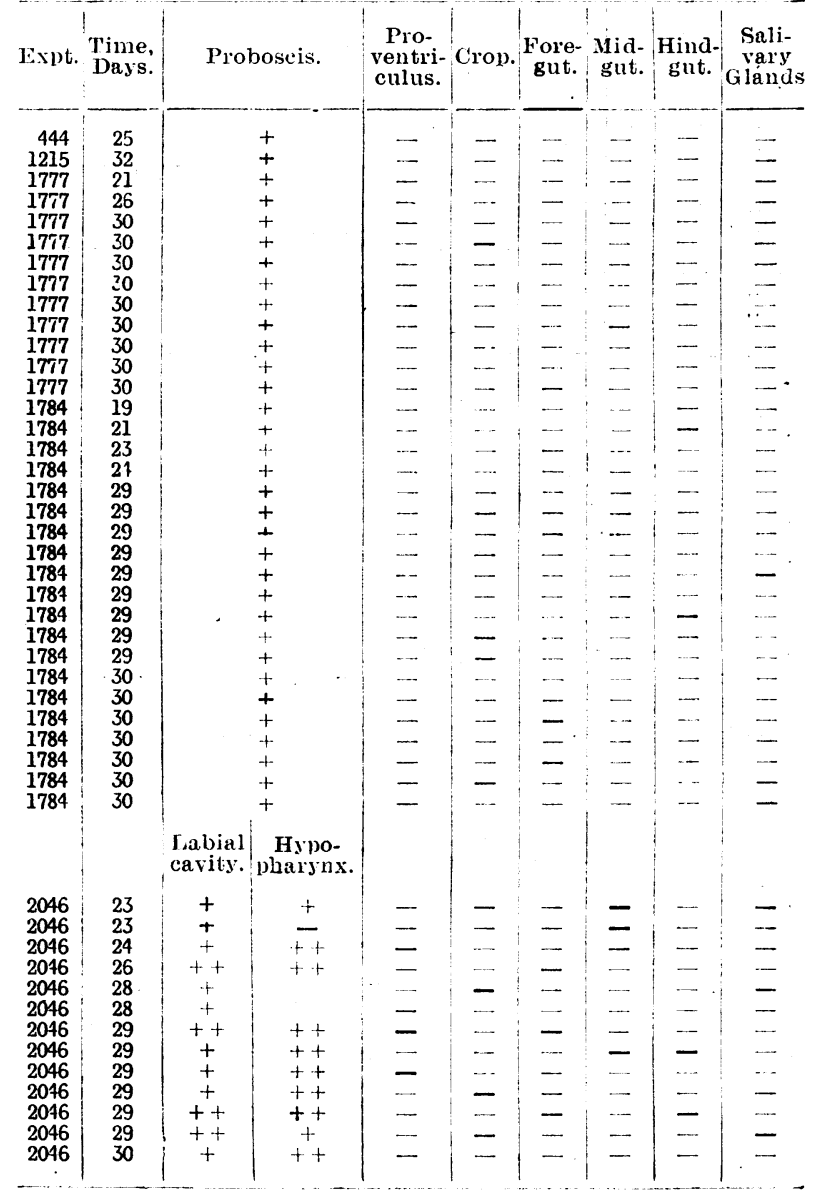

It will be seen from Table XII that it was not until the last experiment that the labial cavity and hypopharynx were examined separately. In the previous experiments the presence or absence of trypanosomes in the proboscis as a whole was noted.

In the first two experiments only a single infected fly was found in each. In Experiment 1777 eleven, and in 1784 as many as twenty were found.

In regard to the number of trypanosomes in the labial cavity this may vary greatly. Sometimes the lumen of the tube will be seen to be densely crowded; at other times a single colony will be seen. For example, in Experiment 1777 the first infected fly, dissected on the twenty-first day, is noted to have had the lumen of the proboscis swarming with clusters of torpedo-shaped flagellates attached to the labrum by their flagellar ends, a ferv swimming free. In the seventh infected fly, dissected on the thirtieth day, only three colonies are noted. In the same way, at one time the hypopharynx may contain few, at another time it is seen to be densely packed with swarms of actively moving trypanosomes. In unstained specimens the difference in size and shape between the trypanosomes in the labial cavity and those in the hypopharynx is quite manifest.

From this table the broad facts stand out boldly-that in this group of trypanosomes the development is confined to the labial cavity and hypopharynx, and does not take place in any other part of the fly. 
The Type of Trypanosomes founit in the Infected Flies.

No attempt was made by the Commission to study the development of Trypanosoma caprae in Glossina morsitans in the earliest stages. This can only be done if a large number of laboratory-bred flies are available, and this was not the case in Nyasaland.

In Figs. 8 and 9 are represented some of the develop mental forms found in the labial cavity and hypopharynx of infected flies. It will be seen that most of the flagellates found attached to the labrum are crithidial in type, with well defined nuclei, micronuclei, and free flagella. Some ax $e$ i i b b o $\mathbf{n}$ sliaped, others have elongated posterior ex tremities, and aga in others are torpedoshaped.

'The last three rows are from the h y pophary n and have been obtained, as a rule, by causing the fly to salivate on the coverglass. They represent tho final stage in the cycle of development, the reversion to the in. fective or blood form. They are rather smaller than those found in the blood of the vertebrate
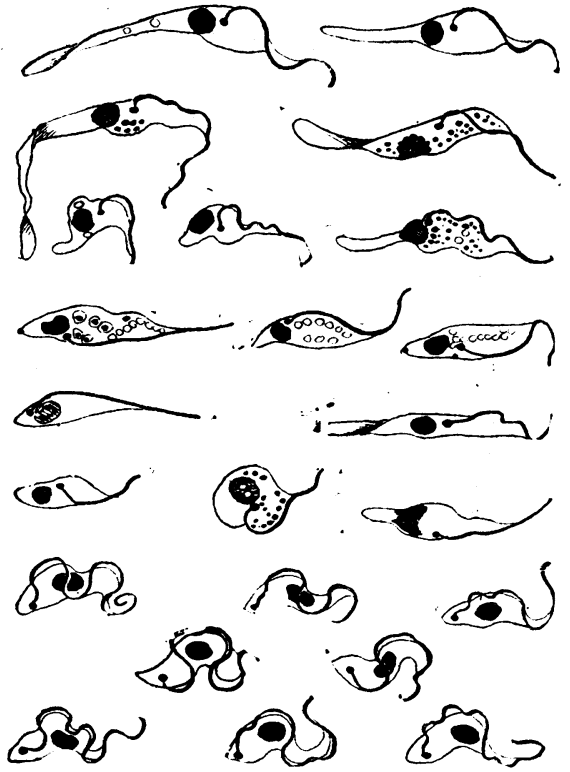

Fig. 8.-Trypanosoma caprac from proboscis. host, but resemble them closely in erery other way.

The Reservoir of Trypanosoma caprac.

Among the 180 wild animals examined in Nyasaland 20 harboured Trypanosoma caprae (11.1 per cent.); 61 per cent. of the waterbuck and 47 per cent. of the reedbuck acted as reservoirs.

\section{Conclusion.}

This concludes the Croonian Lectures on the trypanosomes causing disease in man and animals in Centra Africa. These lectures deal with but a small part of the subject, which has in the course of the last twenty years grown to luuge proportions. Nothing has been said about medicinal treatment, and even measures of prevention have been left a good deal to the imagination. Taking a look back over tho whole field, the outstanding features

\section{ftlumaranda : MEDICAL, SURGICAL, OBSTETRICAL. TREATMENT OF RIGID OS CTERI.}

I Have read with interest Dr. John A. Irvine's communica. tion on this subject in the Joursal of June 12th, p. 1002. The administration of tartar emetic successfuliy rectified the uterine complication. The effects of antimony, howcver, are far from pleasant to the patient, and liable to cause dangerous depression. There is, in my opinion, a better way by which the relaxation of the rigid os uteri may be effected cito, tuto, et jucunde.

As I have pointed out in my book Clinical Memoranda (Baillière and Co.), the application of a tampon of lint or absorbent cotton-wool, soalied in a solution of cocaine, or $\beta$ eucaine (10 grains to the ounce of boric acid solution), to, or into, the os and cervix, acts like a charm.

The irritated nerves and muscular fibres are anaesthetized, and the spasm relaxes directly-even within five minutes-the os dilating widely. On many occasions I may be said to be, first, that some order is beginning to reign in what was lately chaos in regard to the classification of the pathogenic trypanosomes. 'They may all now be referred to three groups, and nine species.

In regard to the transference of the virus from sick to healthy animals by the fly, this has been made clearer and easier of comprehension by the discovery of the part the salivary glands and hypopharynx play in the various modes of development which the trypanosomes undergo in the fly. It results that it would almost appear im. possible for an infective fly to pierce even momentarily

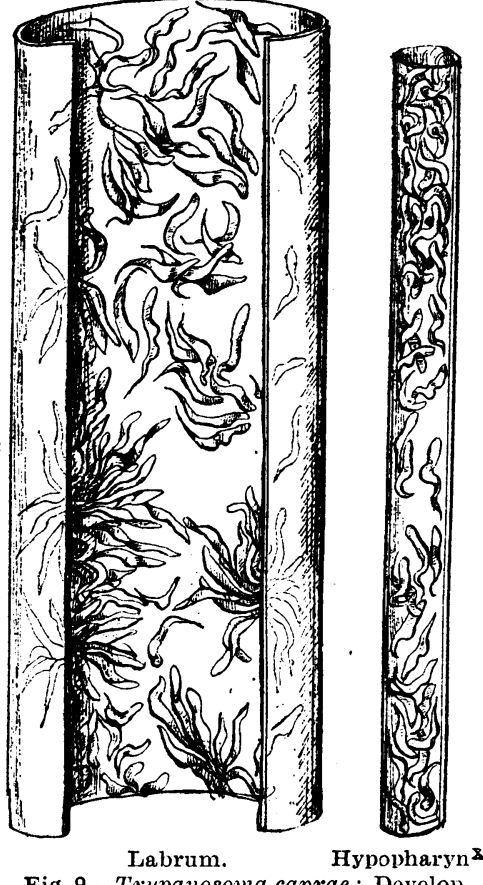

Fig. 9.-Trypanosona caprae: Develop. ment in proboscis. the skin of healtly suscep. tible animal with. out causing in. fection.

Another im. portant feature is the proof brought forward that Trypano. soma bruce $i$ and Trypanosomc rhodesiense are the same.

Finally, in re gard to the pre. veution of these trypanosome dis. eases of man and domegtic animals. We have seen that the wild game in the fly country is heavily infected. It is i m possible to doubt that they are the reservoir and source of many of these diseases. There can be little doubt that if the wild game were driven out of the fly country, trypanosome diseases such as those caused by Trypanosoma brucei and I'rypanosoma pecorum would disappear.

In regard to the measures of prevention against the most important of all the trypanosome diseases-Congo sleeping sickness-it has been shown by experience that the removal of the natives from the fly area is a simple and efficacious way of stopping an epidemic.

In these sparsely inhabited countries where spare land and food are easily obtained, there is as a rule no difficulty in effecting this migration.

If it is desired to go a step further and render the sleep. ing sickness area inluabitable, then clearing and cultivation must be resorted to. By these means in all probability Glossina palpalis will be driven away, and with it the disease.

have had cause to bless this precious drug which has never failed me.

Not only does the cocaine relieve the spasm of the os, but, as the solution spreads all over the vagina, it also anaesthetizes the mucons membrane, permitting the head to pass through the outlet with a minimum of discomfort. Driffield, E. Yorks. A. T. Brand, M.D.

\section{RECURRENT VESICULAR RASH.}

I HAVE at present a young married woman under my care who has a blister which appeared spontaneously over the lower end of the uina. About nine montlss ago a somewhat smaller blister arose over the big toe. I then thought a shoe must have wrung her foot. She had a patch of zoster over the glutei in the winter, and when the ulna bl:ster appeared there was a fresh patch of zoster. All these manifestations were on the left side. She is quite healthy otherwise except for slight grating in some joints and slight occasional asthma. I regard the whole as a manifestation of fibrositis.

Bournemouth.

George Maleaned. 